\title{
Electronic Filing System of Language Innovations in Media: Psycholinguistic Metric
}

\section{Електронна картотека мовних інновацій в медіа: психолінгвістична метрика}

\author{
Larysa Shevchenko \\ Doctor in Philology, Professor, \\ Corresponding member of NAS \\ of Ukraine \\ E-mail: $\underline{\text { shevchenko.knu@gmail.com }}$
orcid.org/0000-0001-6290-2307
}

Dmytro Syzonov

Ph.D. in Philology,

Associate Professor

\section{Дмитро Сизонов}

кандидат філологічних наук, доцент

\section{E-mail: dm sizonov@ukr.net orcid.org/0000-0003-1162-2182 \\ ResearcherID: I-1138-2018 \\ Scopus Author ID: 57209321114}

Kyiv National Taras Shevchenko University, Department of Stylistics and Language Communication $\triangle 60$, Volodymyrska Str., Kyiv, Ukraine, 01033
Київський наџіональний університет імені Тараса Шевченка, кафедра стилістики та мовної комунікацій вул. Володимирська, 60, Київ, Україна, 01033

Original manuscript received December 27, 2018

Revised manuscript accepted August 18, 2019

\section{ABSTRACT}

Objective. The article presents the concept of creating an electronic filing system of language innovations (new vocabulary/phraseology) that updates the material 
of Ukrainian mass media with great attention to its psycholinguistic and functionalstylistic metric. The complex analysis of the e-filing system, which is based on the dynamics of Ukrainian media communication (2016-2018), is the goal of this study.

Materials \& Methods. An innovative author's methodology "10/10: new contexts / new editions" maximally allows to objectify the obtained results and accurately describe them at the relevant time. A special functional-stylistic \& psycholinguistic marking allows to evaluate evolutionary processes in language, analyze the degree of axiology of language resource and predict the time of "life» of language innovation in Ukrainian mass consciousness.

Results. Special lexicographic markers are proposed to help: (a) determine the degree of influence of a new unit on mass consciousness; (b) assess typical / nonstandard communicative situation of appearance of a unit in media; (c) find out the stylistic potential of language innovation in modern Ukrainian. About 1,000 language innovations (words, phraseologisms, semantically and word-transformed units) are represented in the electronic filing system (see author's portal "Language Innovation.UA» on newlexua.blogspot.com on the Google-platform), which are lexicographically represented as a serial dictionary "New words and phraseologisms in Ukrainian mass media» (2016-2018). The theory of media psychology has helped to distribute the material in e-filing system according to evaluative (axiological) dominants (see Martin, J.), pointing to neutral, positive or negative word semantics.

Conclusions. The analyzed material allows to assert that updating of the lexicalphraseological fund of the Ukrainian language has an ongoing nature, an explanation of which is found in the interaction of extra- and intralinguistic factors (particularly, the phenomenon of "linguistic trend" in language innovations of the Western world, multiculturalism, expansion of the information space, etc.). The monitoring of contemporary Ukrainian media made it possible to analyze the causes of replication and consolidation of innovative vocabulary/phraseology in mass consciousness.

Key words: language innovations, media resource, media linguistics, electronic filing system, psycholinguistics, stylistics of the Ukrainian language.

\section{Introduction}

The main objective of the paper is to provide a professional description of new lexemes and phraseologisms that step in to the Ukrainian language through modern media. Linguistic monitoring of media language covers 2016-2018, where intermediate stage is lexicographic fixation of language innovations in the form of a printed dictionary. Current research is focused on establishing psychological parameters of occurrence of new lexems and phraseologisms in mass consciousness, which will allow to comprehensively analyze the 
evolutionary processes in the system of Ukrainian literary language. For this purpose we created original electronic filing system of new words and phraseologisms in the Ukrainian language which has about 1,000 language units and their interpretations in media (genre syncretism and a broad regional principle of the source base allow to present and scientifically describe the investigated resource in the most objective manner). The investigated material is represented in three variants, each of which has its own analysis purpose and internal logic:

(1) on the Google platform blogspot* a blog «Language Innovation.UA» / «Мовні інноваціi.UA» (newlexua.blogspot.com) has been created. The blog represents updating of lexical and phraseological fund of the Ukrainian language presented in mass media (printed and web media, television and radio, advertising);

(2) in paper version of annual peer-reviewed dictionary «New words and phraseologisms in Ukrainian media» (Shevchenko \& Syzonov, 2017a; Shevchenko \& Syzonov, 2018) frequency illustrative material is presented that allows to observe evolutionary processes in modern language communication;

(3) electronic register of new words and phraseologisms with markings in the form of lexicographic marks, which allows to analyze in what circumstances and conditions language innovation is included in media discourse and reproduced in mass consciousness. It is worth noting that communicative reality, recipients background knowledge, genre syncretism, audience etc. affect the different degree of stylistic expression (the electronic projectis aimed at investigating the abovementioned notions, which confirms the relevance of our research).

The establishment of electronic filing system is dominant in modern lexicography, which is confirmed by numerous publications in world peer-reviewed editions, using the example of English, Lithuanian and Polish languages (Rodríguez, 2017; Naktinienè, 2012; Majewska 2012 etc.). The innovativeness of the proposed web filing system is confirmed by the fact that for the first time in Ukrainian virtual

\footnotetext{
* Blog hosting Google is free of charge which is provided by the company's policy and freely available [https://www.blogger.com/content.g?hl=en-GB]. Our project newlex.blogspot.com is not of a commercial nature. It is created for educational and informational purposes, has no violations of ethical policy, legal norms, does not endanger social and political system. All copyrights on technical parameters of the blog belong to Pyra Labs company. Copyrights on the content of the blog belong to L.I. Shevchenko and D.Y. Syzonov. There is no advertising on the platform.
} 
lexicography a media resource is not simply recorded using computer technologies, but also provided by tag markers which allow to recreate the actual picture of updating of the lexical-phraseological fund of the Ukrainian language (i.e., an indication on the origin of the word, affiliation to a certain sphere of communication, type of assessment in mass consciousness, semantic marker etc.).

\section{Data and Methods}

I. The working concept of the new dictionary and the methodology for its creation have already been described earlier (Shevchenko \& Syzonov, 2017b). The methodology for organizing the electronic filing system is based on the principle of register of linguistic units in a web-format. Thus, register of new words and phraseologisms on the platform is carried out according to the alphabetical principle (discursiveness of the filing system is indicated by a broad commentary - an interpretation of a definition and an indication to the communicative sphere).

The certification of a new linguistic phenomenon with an appropriate media illustration is provided in lexicographic works in the paper version (Shevchenko \& Syzonov, 2017a; Shevchenko \& Syzonov, 2018).

II. Taking into account frequency and typicality of functioning of a new unit (a new meaning) in media context is significant for the criterion of novelty of semantics which allows to objectify the dynamics of the development of modern Ukrainian as a real source of replenishment of active vocabulary. In this aspect, in our opinion, several methods of lexicography are relevant:

(a) method of typological comparisons in search and scientific certification of neologisms, which was used as basic and one that corresponds to the correctness of the presented neo-lexemes (a new word, recorded taking into account background knowledge of the recipients, a functional marker of a particular time interval). Such an approach enabled the authors to prove the main principle of appearance and fixing of neologism in media communication represented in the edition.

(b) method of conceptualizing the principles of systematic representation of new language units in media. The above-mentioned 
universal method includes media monitoring which allows to fully describe media sources of modern Ukraine. Thus, continuous sample of linguistic material by means of this method includes media texts of various spheres (political, economic, cultural and artistic, educational), genres (informational-analytical, fiction and publicistic group of genres of printed and electronic press) and means of communication (radio, television, Internet).

(c) lexicographic interpretation method, that was used for analysis of the collected material, its certification and linguistic argumentation of its novelty (a nominative unit with an interpretation is presented in the electronic filing system, a broad functional-stylistic interpretation is represented in the printed version of the dictionary).

(d) for maximal search objectification the author's methodology for collecting material had been developed, which correlates with world practice of compilation of functional dictionaries. The compilers of the electronic filing system were guided by the author's principle «10/10: new contexts / new editions», i.e. fixation of an innovative linguistic unit in 10 media contexts of 10 media sources, which indicates the tendency of an innovation unit to be replicated in media and captured in mass recipient's memory.

III. Marking of innovative units in the electronic filing system was carried out with the help of a system of functional-stylistic and psycholinguistic metrics, which allowed to explain the reasons for further replication of a linguistic innovation in the system of the Ukrainian literary language.

\section{Results and Discussion}

We emphasize that similar electronic registers are not new to world media space: let us recall Polish («Młodzieżowe słowo roku»), Russian («Русский язык, 21 век: новые заимствованные слова»), French («Nouveaux mots dans la langue»), Ukrainian («Мислово») projects. However, in Ukraine in the context of media linguistic analysis such an investigation is conducted for the first time. The project «Language Innovation.UA» is primarily logical in the context of time (as for the 21 st century lexicography) and material objectification (it is an electronic continuation of the serial dictionary «New words and phraseologisms in 
Ukrainian mass media» (Shevchenko \& Syzonov, 2017a; Shevchenko \& Syzonov, 2018)).

The search for new words and their electronic presentation for Ukrainian lexicographic reality is innovative, based on a unique method «10/10: new contexts / new editions». The author's technique has not been presented earlier, especially in the context of psycholinguistic metric analysis. We believe it necessary to stress that the psycholinguistic parameters of media communication have been already considered in several scientific works devoted to fake news manipulation (Keersmaecker \& Roets, 2017), psycholinguistic parameters in advertising (Harris, Klassen \& Bechtold, 2012), psychological and linguistic interaction of social media (Hwong, Oliver, Kranendonk \& Sammut, 2017) etc. However, the analysis of psycholinguistic metrics on the basis of Ukrainian media is conducted for the first time (the achievements of world psycholinguistics only reinforce the results of our investigation).

In addition, our filing system contains not only new words, but also new idioms, which we consider a fresh look in Ukrainian neolexicography. In this context, we recall a comprehensive scientific review on virtual representation of English idioms, including its lexicographic aspects, carried out by Moon (Moon 2015: 319-320). We also mention world scientific projects on collecting, analyzing and compiling new vocabulary:

(1) a project for collection, analysis and register of linguistic material on the basis of Russian media under the guidance of prof. Solhanyk (the author's methodology was based on a systematic collection of new / updated vocabulary from newspapers and magazines);

(2) a project of the Institute of Linguistic Studies, which provided for compiling of linguistic material on the basis of press and journalistic literature of the 60-90s of the 20th century;

(3) a Polish lexicographic project of the Center of Press Researches at Jagiellonian University (headed by Pisarek, 2006). The Polish scholar Pisarek is the author of the electronic online project «Polskie media», which unifies and presents media terminology / terminology combinations / scientific phraseology in Poland. In 2011, Polish linguists publish an analogue of 
the vocabulary of media terms by Pisarek in translation into English, French and German;

(4) a British project of Oxford University (Oxford Word of the Year). Every year, the Oxford University Press publishes the most popular word for mass communication, which has become the most commonly used, primarily in the Internet discourse. For instance, according to the results of 2018, the word «toxic» («poisonous», first appeared in English in the mid-seventeenth century, from the medieval Latin toxicus, meaning «poisoned» or «imbued with poison») became popular in English ${ }^{* *}$.

Obviously, we relied on Ukrainian school of computer linguistics, where the major role in creating an electronic base of language units belongs to different types of electronics, which helps not only to systematize but also to classify the units according to certain parameters (see the achievements of Ukrainian lingua-information fund of NAS of Ukraine in this direction at http://www.ulif.org.ua/).

In world peer-reviewed editions there had been attempts to describe the electronic filing system in system-structural aspect (Karpilovska, 2017; Ivancova, 2013; Quasthoff, Liebold \& Taubert, 2007); yet in the functional-stylistic aspect with a focus on psycholinguistics the proposed research is carried out for the first time. The logic of analysis and creation of electronic databases and filing systems is determined by urgent problems in (neo)linguistics, which is revealed in global computerization of all spheres of human activity, including languages as well as in concepts of creating the electronic dictionary of the future (Shyrokov, 2004) and perspective tasks of syncretic connection of linguistics and informatics (Williams, 2016). A confirmation of our position is found in such thoughts of scholars:

(1) Computerization of modern lexicography is not just a desire to provide scientific and technological progress in this field [...]. The combination of achievements of traditional lexicography with new methods created by information science sets out the task of developing highly effective lexicographic technologies that are capable of solving fundamentally new problems posed by linguistics in the information age ${ }^{* * *}$ (Shyrokov, 2004: 65).

\footnotetext{
** https://en.oxforddictionaries.com/word-of-the-year/word-of-the-year-2018

${ }^{* * *}$ hereinafter the translation of citations into English is ours.
} 
Electronic Filing System of Language Innovations in Media...

(2) European electronic lexicography network demonstrates that we can use our huge web as a broad potential. In terms of lexicography the time challenge is connected with science informatization, where vocabulary remains the leading «bridge» between linguistics and computer science (Williams, 2016: 79).

(3) With the development of computer technologies the fourth component was added to the traditional three-part chain of the dictionary creation - the electronic register, [...] base, balanced and indicative for the real state of the language system in a certain period of its existence as a model of «language in action» (Karpilovska, 2017: 94).

One of the innovators of systematic computer (the so-called corpus) dictionary compiling Lendau (Lendau, 2012) rightly reminded lexicographers that «a corpus is always a selection and can represent only speech and writing of selected transcripts and texts» (Lendau, 2012: 316). Due to the increase of corpuses and methods of their compiling lexicographers will have to rely on software tools (we offer such new tools in electronic filing system compiling in the framework of the author's project «Language Innovation.UA»). All innovative computer-type dictionaries are developed within strict time constraints, as «a new word / phrase is a reaction to time and background knowledge of communicants who use these language innovations» (Moon, 2015: 330). Nobody will have time to sort thousands or even hundreds of thousands of fixations in order to find a specific word usage that needs to be presented in a dictionary (in this context, an electronic filing system is a very convenient and rational variant). Innovative computer technologies with their special multi-function to participate in dictionary compiling today rank first among all new dictionaries in the United States, Great Britain, France, Japan and other developed countries.

We should emphasize that nowadays the use of dictionaries of the late $20^{\text {th }}$ century involves focusing on anthropocentric approach and pragmatic «dictionary-user» attitude. According to researcher Salzmann (Salzmann, 2002), for effective use of a lexicographic source it is necessary to choose the appropriate type of vocabulary which will adequately meet the user's needs, to know the main components at the macro- and microstructural levels, to easily find a required registry unit and adequately perceive information about the linguistic unit in a lexicographic work. 
Modern theories of innovative dictionaries creation in Ukraine and the world are built on functional pragmatics. Instructions for such dictionaries, their structure, collection of material and actual compiling were made at the beginning of the $21^{\text {st }}$ century by foreign (Williams, 2016; Quasthoff, Liebold \& Taubert, 2007) and Ukrainian (Taranenko, 2000; Shevchenko \& Syzonov, 2017b; Shyrokov, 2004) scholars.

Referring, for instance, to the work by Taranenko (2000), we emphasize that it basically substantiates the principles of compiling completely new dictionaries with a new verbal reality: around semantic and stylistic aspects of Ukrainian vocabulary in the first place. Publication of theoretical and practical literature of this type will contribute to codification of already existing principles for vocabulary products compiling and development of new approaches in practical lexicography.

In 2010, Taranenko emphasizes the actualized models in the system of word / phrase formation of modern Ukrainian. When compiling registers, the author proposes taking into account active development of the Ukrainian language associated with extralinguistic motivation massive usage of a linguistic unit in speech. We emphasize three main factors of derivative-nominative processes in the emergence of new words/meanings: (1) a comprehensive renewal of language composition in post-Soviet times, which manifests itself in new socio-political, cultural, economic and other vectors; (2) the need to systematize and standardize various segments of the word-formation structure of the Ukrainian language, search for its identity and return to the so-called normative ideals; (3) expansion of the sources of replenishment of the active Ukrainian vocabulary: from conversational elements, vernacular, youth slang, political slang to the stylistic phenomenon of language game, occasional word-formation, stylistic transformation etc. We believe that these factors can be expanded due to the fact that nowadays language as a system has a great external influence. Therefore, the expansion of its functional boundaries is unlimited (Taranenko, 2000: 67).

According to the present challenges in 2019 we launched an electronic filing system of new words and phraseologisms on the Blogger.com platform owned by Google Inc. The material for newlexua. blogspot.com has been gathered since $2016^{* * * *}$. The total number of

\footnotetext{
**** The project is of educational character, which involves the participation of students of the specialty "Media linguistics» in collecting and compiling dictionaries of new vocabulary and phraseology in Ukrainian mass media (headed by prof. L.I. Shevchenko).
} 
language units presented in the platform is about 1.000, which gives grounds to speak about constant evolution of the Ukrainian language, primarily updating of the lexical-phraseological fund due to mass media resources.

The distribution of language innovations over the years is as follows:

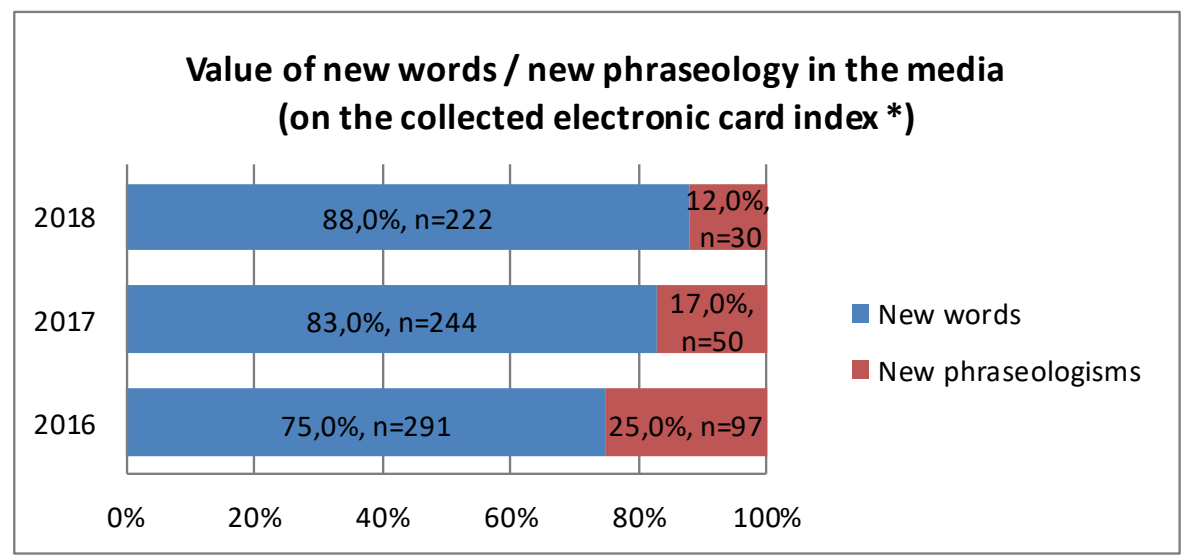

Figure 1. New words and phraseologisms in Ukrainian mass media (2016-2018)

*continuous updating of the filing system witnesses to constant process of entering/ exiting of linguistic units in the Ukrainian language system. Data is updated on a monthly basis.

The principle of electronic filing system compiling is influenced by logical evolution in the triad of concepts «journalist - time recipient»:

(a) a journalist who replicates language innovations in mass media;

(b) time within which a new linguistic unit appeared;

(c) a recipient. Due to his professional knowledge new units are relaying outside mass media.

In the process of e-filing system compiling we have used the above-mentioned facts in their functional-stylistic interdependencies.

In 2019 (the print version of the dictionary will be published at the end of the calendar year) the principle of language innovations presentation is preserved, which is correctly represented on the site in the form of a separate structured article ++++ :

As of today, it is not the fact of the growing number of computer systems for dictionaries of a new type itself but rather the principles of electronic filing system compiling that remain debatable. In this context, let us recall a monograph by a leading Austrian linguist 
Toshovich (Tošović, 2018) within the framework of a research on generative linguistics (on the mechanisms of functioning of language units in electronic formats, the creation of web corpuses at the level of structure and taxonomy). As stated above, separate works on electronic dictionaries compiling were thoroughly developed by Ukrainian scientists (Shyrokov, 2004; Taranenko, 2000; Karpilovska, 2017).

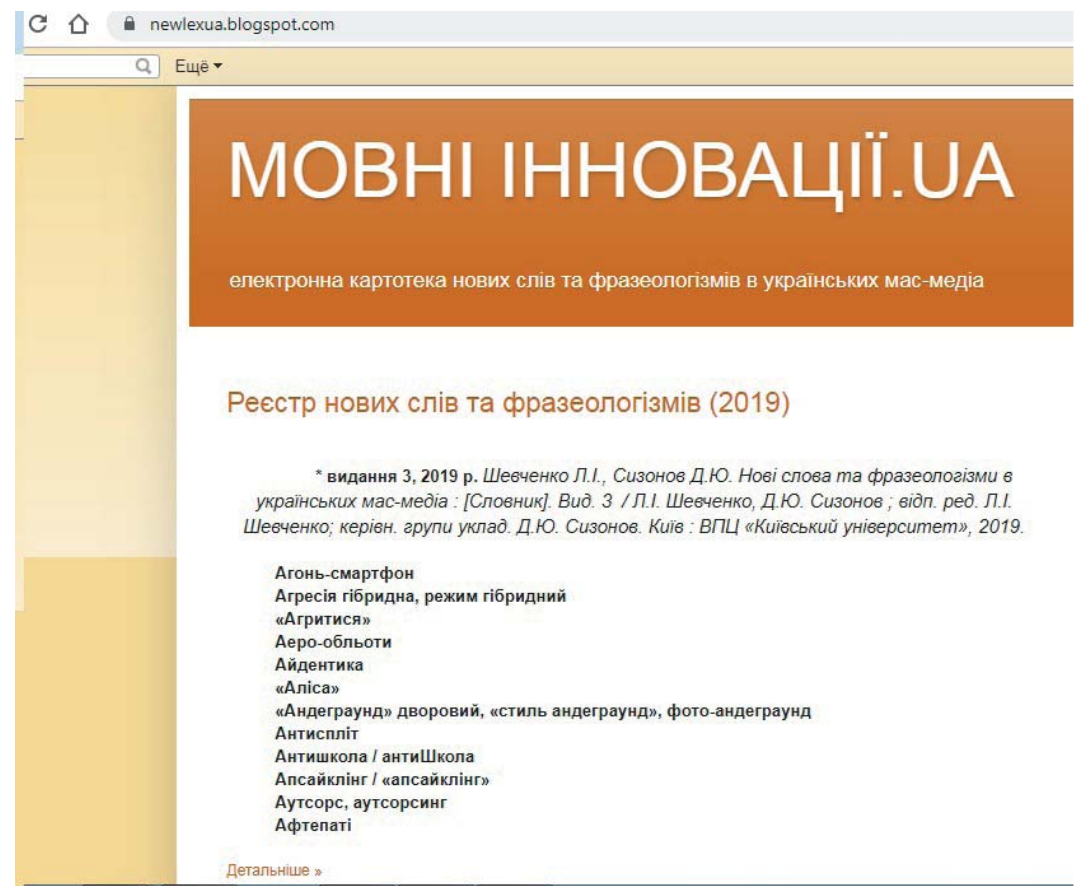

Scr 1. Web site newlex.blogspot.com

We note that extralinguistic communication factors are important criteria for the correct marking of vocabulary articles in the electronic filing system. They are currently dominant in stylistics, in particular when it comes to integration of linguistic innovations into the literary language (Gajda, 2012: 12; Tošović, 2018). Such markings help to determine from which sphere the unit has fallen into the language and / or in which area the unit functions in a new status. We have presented the identification marks in the form of lexicographic markings in «Principles of the dictionary compiling» (Shevchenko \& Syzonov, 2017a: 6-15; Shevchenko \& Syzonov, 2018: 7-14). This allows to correctly explain the causes of emergence and subsequent functioning of innovations in 
language as well as observe real dynamics of language system. In the electronic filing system we propose a system of identification marks that argue for scientific consistency of work on the dictionary (in paper and electronic versions).

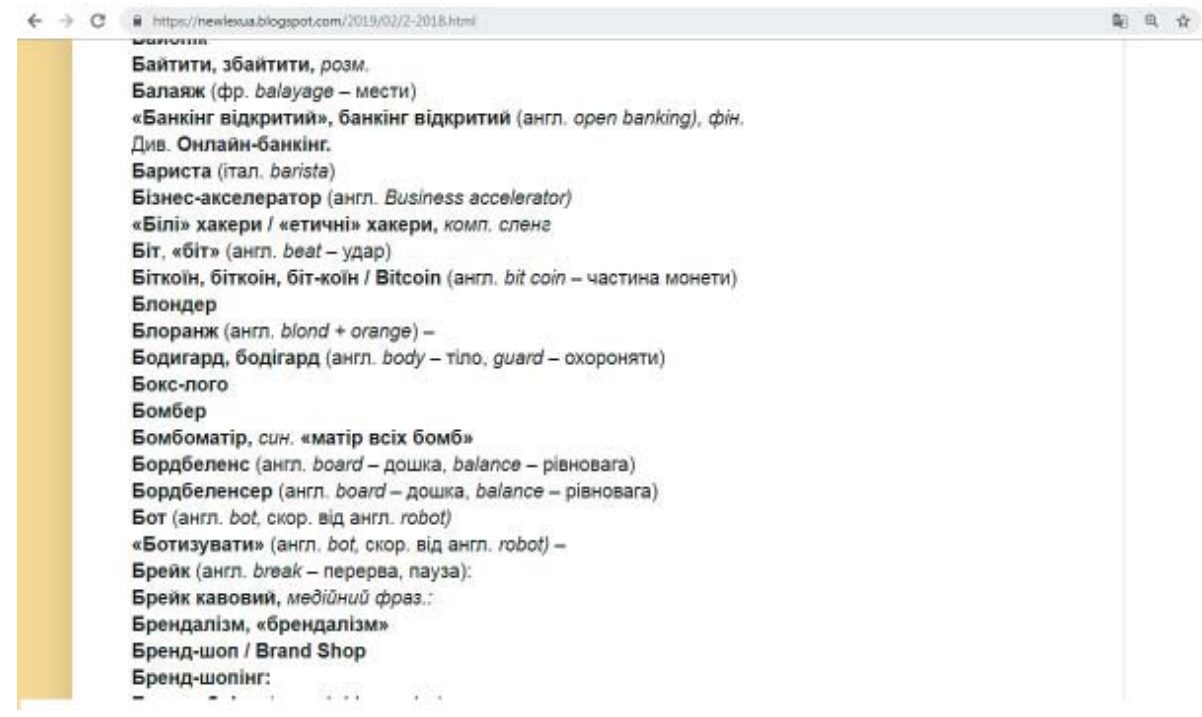

Scr 2. Web site newlex.blogspot.com

Using the search engine on the web platform, one can easily find the necessary mark and group the language innovations with certain parameters:

(a) a communicative sphere in which the language innovation exists: political, cultural, etc.;

(b) the word etymology (according to those circumstances in which the word had appeared and exists in the Ukrainian language): English, French, Russian;

(c) marking on literary / non-literary affiliation of the neologism: jargon, slang, invective lexeme;

(d) evaluation characteristics: positive, negative, neutral.

Functional-stylistic metric indicates the dynamic processes of the Ukrainian language development and helps to identify the innovative language unit in the lexical-phraseological stream; psycholinguistic metric aims to explain the evaluation potential of a new word in the system of the Ukrainian language. 


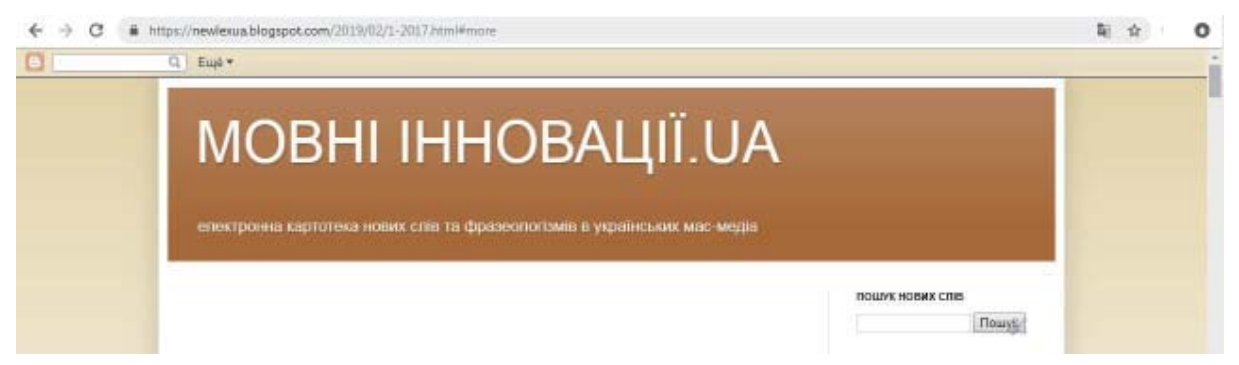

Scr 3. Web site newlex.blogspot.com (start page)

We emphasize on the evaluation scale which is represented in the form of the linguistic unit marking in the electronic filing system. The latter includes expanded and adapted to modern reality scale of word / phrase meanings in media (Martin, 2012; Martin \& White, 2005) and search meanings in linguistic units which is reflected in mass consciousness. We stress that axiological analysis of new units in communication is unexpected for the scientific discourse (see thorough research conducted by a social psychologist Schwartz (Schwartz, Melech \& Burgess, 2001)). We have already presented separate results of media and psycholinguistic studies (on the example of phraseological innovations) (Syzonov, 2018). We present new results according to the collected language units of the electronic filing system, where the labeling negative, positive or neutral was formed in accordance with contexts in which new words / phraseologisms were functioning. The distribution of material in the e-filing system is easy to do with the help of computer programming by setting the required parameters. Let us display it in the form of a diagram (Figure 2).

Paradoxically, the largest number of new linguistic units presented in electronic filing system has negative semantics $(56,0 \%, \mathrm{n}=523)$, which, in our opinion, is explained by extralinguistic factors related to social, economic and political situation in the country, the search for new linguistic forms to traditional notions. Among the words with negative semantics most of the lexemes are from military-political sphere (the donor here is not only the terminology of the literary language, but also extra-linguistic vocabulary and phraseology): Cenap, negative; "Кремлебот", negative; вірус "Росія", negative; операція "Гречка", negative; справа "рюкзаків", пеgative; кібер-тітушкі, negative etc. 


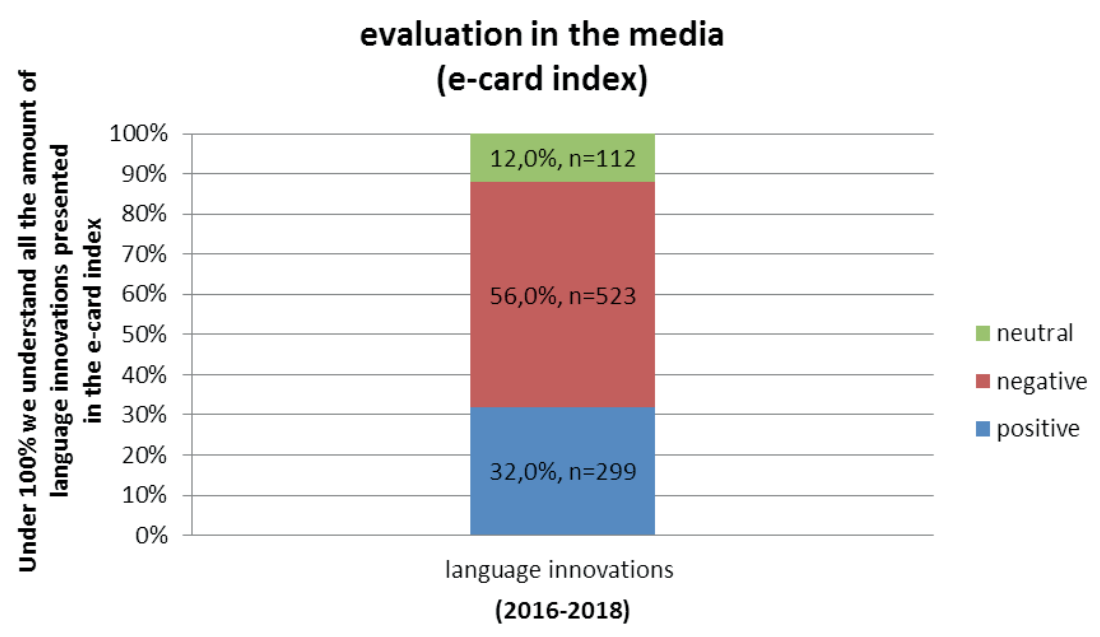

Figure 2. The metric of evaluation in the media (2016-2018)

Positive evaluative nomination $(32,0 \%, \mathrm{n}=299)$ accounts for over a third of the lexemes and is mainly related to socio-political processes in Ukraine / the world: євромайбутнє, роsitive; П'ятирічка Гросмана, роsitive; інстадвіж, роsitive; айдентика, роsitive; Велоконцепція, positive; АТОшник, positive etc.

Neutral evaluation is the least $(12,0 \%, \mathrm{n}=112)$, which is quite logical, since entry of a new linguistic unit is always accompanied by a certain subjectivity, a personal communicant's experience who verbalizes phenomena of the real world. Most innovation units with a neutral evaluation are terms and term combinations that de facto do not carry evaluative nomination (e.g. героскутер, neutral; Ейчар / айчар, HR - neutral; криптомат, neutral; Юнікод / Unicode - neutral etc.).

It is noteworthy that some nominations may change their evaluative characteristics due to rethinking of semantics (e.g. "Ipмa», neutral a nomination of a powerful Atlantic tropical cyclone of $5^{\text {th }}$ category and "Iрма", figurative meaning - a destructive force in economy, politics and other branches; Свропаркан/«європаркан» - 1) neutral, a fence of concrete slabs, popular in construction; 2) figurative meaning, a wall on the border with Russia, etc. See an example of the selection of language innovations for the search (Scr 4).

By courtesy of electronic filing system we can correctly represent and describe these phenomena in language, which will help to properly 
provide the dynamics of changes of actual language resource in the mass consciousness of Ukrainians.

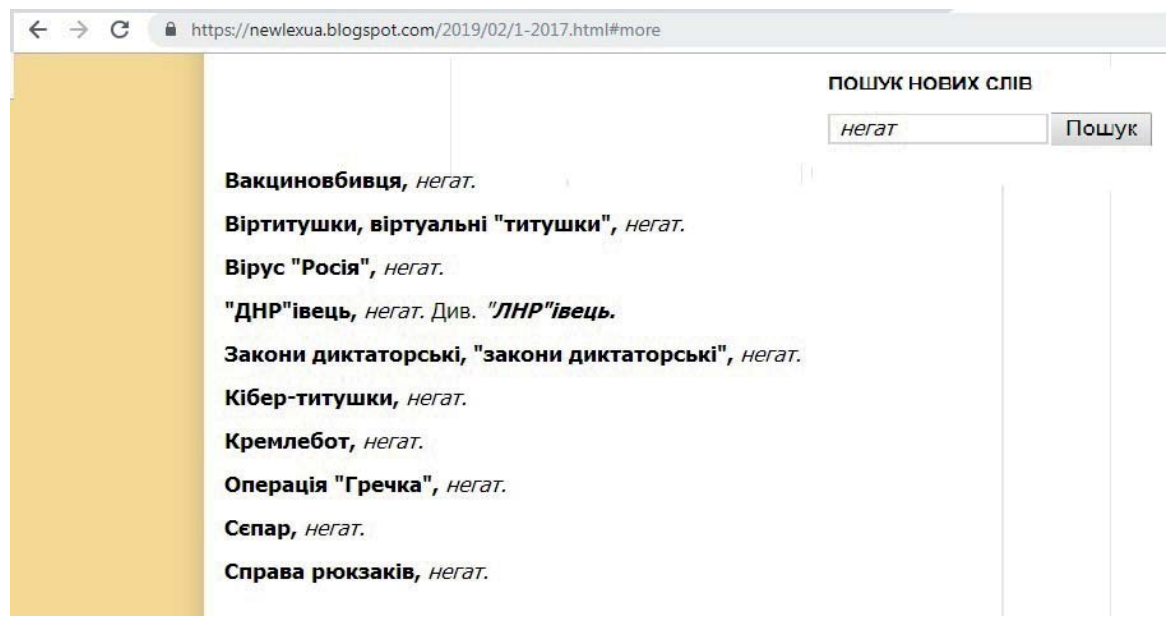

Scr 4. Web site newlex.blogspot.com

\section{Conclusions}

For correct representation of linguistic units in electronic form it is significant to indicate:

(1) the communicative sphere, in which a linguistic unit appears and continues to function (it is represented by markings political, social, cultural, musical etc.). This allows to trace the movement of the linguistic unit in the communication process;

(2) primary or secondary nomination, that proves the stylistic potential of a linguistic unit in mass communication (especially interesting is transition from one type of nomination to another due to rethinking of semantics of a word / a phraseologism in mass consciousness);

(3) the origin of a word / a phraseologism, when it comes to replenishing the lexical-phraseological fund of the language with a resource from other languages (in connection with integration of Ukraine into European space the donor language is mostly English, which is also confirmed by our electronic register);

(4) availability of non-literary units of language as an instrument for updating lexical-phraseological fund of the Ukrainian language (this 
is implemented in the form of lexicographic markers such as youth slang, jargon, invective lexeme etc.).

According to all types of marking it is possible to classify and group linguistic innovations in order to see the real picture of language system evolution, the changes in its composition, the axiological dominants that form modern linguistic communication as well as trace the «life» of a linguistic unit in relative time frames.

\section{References}

Ivancova, E. (2013). Leksikograficheskoe predstavlenie rechi individa: tip slovarja $i$ ego realizacija $v$ slovarnoj praktike [Lexicographic representation of the speech of the individual: type of dictionary and its implementation in vocabulary practice]. Voprosy leksikografii - Russian Journal of Lexicography, 2(4), 6-18 [in Russian].

Gajda, S. (2015). Aktualnye zadachi stilistiki [Topical issues of stylistics]. Aktualnye problemy stilistiki - Actual Problems of Stylistics, 1, 11-22 [in Russian].

Hwong, Y., Oliver, C., Kranendonk, M., \& Sammut, Y. (2017). What makes you tick? The psychology of social media engagement in space science communication. Computers in Human Behavior, 68, 480-492. https://doi.org/10.1016/j. chb.2016.11.068

Harris, R., Klassen, M., \& Bechtold, J. (2012). Language in Advertising a Psycholinguistic Approach. Current Issues and Research in Advertising, 9, 1-26.

Karpilovska, Je. (2017). Rol kartoteky «portretiv sliv» v ukladanni slovnykiv novogo pokolinnja [The role of «portraits of words» card index in the compiling of new generation dictionaries]. Studia z Filologii Polskiej $i$ Stowiańskiej, 52, 93-109. https://doi.org/10.11649/sfps.2017.005 [in Ukrainian].

Keersmaecker, J. de, \& Roets, A. (2017). 'Fake news': Incorrect, but hard to correct. The role of cognitive ability on the impact of false information on social impressions. Intelligence, 65, 107-110. https://doi.org/10.1016/j.intell.2017.10.005

Lendau, S. (2012). Slovnyky: Mystetstvo ta remeslo leksykohrafii [Dictionaries: the art and technic lexicography]. (O. Kocherha, Trans.). Kyiv: «K.I.S.» [in Ukrainian / in English].

Majewska, Małgorzata B. (2012). Zdygitalizowany słownik języka polskiego jako pomoc w pracy językoznawcy - na przykładzie edycji elektronicznej Słownika wileńskiego. Język Polski, 92(5), 381-390 [in Polish].

Martín, J. (2012). Lexical database, derivational map and 3D representation. Journal of Applied Linguistics, Extra 1, 119-144.

Martin, J., \& White, P. (2005). Evaluative key in journalistic discourse - the 'voices' of news, analysis and commentary. In Martin, J., \& White, P. (Eds.), The Language of Evaluation (pp. 164-184). https://doi.org/10.1057/9780230511910_4

Moon, R. (2015). Idioms: A View From the Web. International Journal of Lexicography, 28(3), 318-337. https://doi.org/10.1093/ij1/ecv023

Naktinienė, G. (2012). Elektroninio Lietuvių kalbos žodyno naujovès. Kalbos kultura, 85, 92-102 [in Lithuanian]. 
Quasthoff, U., Liebold, S., \& Taubert, N. (2007). Struktur und Auswahl des Wortschatzes. In Quasthoff, U. (Ed.), Liebold, S., \& Taubert, N. Deutsches Neologismenwörterbuch: Neue Wörter und Wortbedeutungen in der Gegenwartssprache. Berlin; New York: Walter de Gruyter, 17-24. https://doi. org/10.1515/9783110911138 [in German].

Pisarek, W. (2006). Słownik terminologii medialnej. Kraków [in Polish].

Rodríguez, D. (2017). On the applicability of the dictionaries of Old English to linguistic research. Journal of English Studies, 15, 173-191. http://dx.doi. org/10.18172/jes.3208.

Salzmann, Z. (2002). Modern Lexicography: An Introduction (review). Language, 78(2), 391-392. https://doi.org/10.1353/lan.2002.0127

Schwartz, S.H., Melech, G., \& Burgess, S. (2001). Extending the cross-cultural validity of the theory of basic human values with a different method of measurement. Journal of Cross Cultural Psychology, 32, 519-542. https://doi. org/10.1177/0022022101032005001

Shevchenko, L., \& Syzonov, D. (2017a). Novi slova ta frazeologizmy v ukrainskyh mas-media [New words and phraseologisms / idioms in the Ukrainian mass media: dictionary]. Kyiv: Kyivskyj universytet [in Ukrainian].

Shevchenko, L., \& Syzonov, D. (2017b). Pryncypy leksykografichnoi reprezentacii novyh sliv ta frazeologizmiv $\mathrm{u}$ mas-media [Principles of lexicographic representation of new words and phraseology in mass media]. Actualni problemy ukrayinskoyi lingvistyky: teorija i praktyka - Actual issues of Ukrainian linguistics: theory and practice, 34, 76-85. https://doi.org/10.17721/ APULTP.2017.34.76-85 [in Ukrainian].

Shevchenko, L., \& Syzonov, D. (2018). Novi slova ta frazeologizmy v ukrainskyh masmedia [New words and phraseologisms / idioms in the Ukrainian mass media: dictionary]. Kyiv: Kyivskyj universytet [in Ukrainian].

Shyrokov, V. (2004). Fenomenologija leksykografichnyh system [Phenomenology of lexicographic systems]. Kyiv: Naukova dumka [in Ukrainian].

Syzonov, D. (2018). Media Phraseology and the Dynamics of the Ukrainian Language: The Psycholinguistic and Stylistic Paradoxes. Psikholingvistika Psycholinguistics, 24(2), 277-291. https://doi.org/10.31470/2309-1797-2018-24-2277-291

Taranenko, O. (2000). Novyj slovnyk ukrainskoi movy: Koncepcija i pryncypy ukladannja slovnyka [A New Dictionary of the Ukrainian Language: Concepts and Principles for Compiling a Dictionary]. Kyiv: Nacionalna akademija nauk Ukrainy [in Ukrainian].

Tošović, B. (2018). Generatorska lingvistika. Beograd: Svet knjige [in Serbian].

Williams, G. (2016). In Praise of Lexicography, and Lexicographers. Proceedings of the XVII EURALEX International Congress (pp. 77-88).

\begin{abstract}
АНОТАЦІЯ
Мета дослідження. У статті розглянуто концепцію створення електронної картотеки мовних інновацій (нової лексики/рразеології), що актуалізує матеріал українських мас-медіа з увагою до його психолінгвістичної та функціонально-стилістичної метрики. Комплексний опис е-картотеки, в
\end{abstract}


основі якої динаміка україномовної медіакомунікації (2016-2018 рр.), є метою даного дослідження.

Методики дослідження. Нова авторська методика «10/10: нові контексти / нові видання» дозволяє максимально об'єктивувати отримані результати та точно описати їх в актуальний для реципієнта час. Спеціальне функціональностилістичне та психолінгвістичне маркування дозволяє оцінити еволючійні процеси в мові, проаналізувати ступінь аксіологічності мовного ресурсу та спрогнозувати час "життя» мовної інновації в українській масовій свідомості.

Результати. Запропоновано спеціальні лексикографічні маркери, що допомагають: (а) визначити ступінь впливу неоодиниці на масову свідомість, (б) оцінити типову / нестандартну комунікативну ситуацію появи одиниці в медіа, (в) з'ясувати стилістичний потенціал мовної інновації в сучасній українській мові. В електронній картотеці (див. авторський портал "Мовні інноваціi.UA» newlexua.blogspot.com на Google-платформі) репрезентовано близько 1.000 мовних інновацій (слів, фразеологізмів, семантично і словотвірно трансформованих одиниць), що лексикографрічно представлені як серійний словник "Нові слова та фразеологізми в українських мас-медіа» (2016-2018). Теорія медіапсихології допомогла розподілити матеріал у е-картотеці за оцінними (аксіологічними) домінантами (Martin, J.), вказуючи на нейтральну, позитивну та негативну семантику слова.

Висновки. Проаналізований матеріал дозволяє стверджувати, що оновлення лексико-фразеологічного фонду української мови відбувається постійно, пояснення чому знаходимо у взаємодії екстра- та інтралінгвальних факторів (зокрема, явище "лінгвістичної моди» на мовні інновації Заходу, полікультурність, розширення меж інформаційного простору та ін.). Проведений моніторинг сучасних українських медіа дозволив проаналізувати причини тиражування та закріплення в масовій свідомості інноваційної лексики / фразеології.

Ключові слова: мовні інновачії, медіаресурс, медіалінгвістіка, електронна картотека, психолінгвістика, стилістика української мови.

Шевченко Лариса, Сизонов Дмитрий. Электронная картотека языковых инноваций в медиа: психолингвистическая метрика

\section{АННОТАЦИЯ}

Цель исследования. В статье представлена концепция создания электронной картотеки языковых инноваций (новой лексики/фразеологии), основывающаяся на материале украинских масс-медиа и акцентирующая внимание на психолингвистической и функционально-стилистической метрике. Комплексный анализ е-картотеки, в основе которой лежит динамика украиноязычной медиакоммуникации (2016-2018), является целью данного исследования.

Методики исследования. Новая авторская методика «10/10: новые контексты/новые издания» позволяет максимально объективировать полученные результаты и точно описать их в актуальное для реципиента 
Електронна картотека мовних інновацій в медіа...

время. Специальные функционально-стилистические и психолингвистические маркировки позволяют оценить эволюционные процессы в языке, проанализировать степень аксиологичности языкового ресурса и способствуют прогнозированию времени «жизни» языковой инновации в украинском массовом сознании.

Результаты. Обосновываются разработанные автором специальные лексикографические маркеры, помогающие: (а) определить степень влияния на массовое сознание языковыми неоединицами, (б) оценить коммуникативную ситуацию появления единицы в медиа, (в) стилистический потенциал языковой инновации в современном украинском языке. В электронной картотеке (см. авторский портал "Языковые инновации.UA» newlexua.blogspot.com на Google-платформе) представлены около 1.000 языковых инноваций (слов, фразеологизмов, семантически и словообразовательно трансформированных единиц), лексикографически представленных в виде серийного словаря «Новые слова и фразеологизмы в украинских масс-медиа» (2016-2018). Теория медиапсихологии помогла распределить материал электронной картотеки по оценочным (аксиологическим) доминантам (Martin, J.), указывая на нейтральную, положительную и отрицательную семантику слова.

Выводы. Собранный материал позволяет утверждать, что обновление лексико-фразеологического фонда украинского языка происходит постоянно, объяснение чему находим во взаимодействии экстра- и интралингвистических факторов, определяющих динамику развития языка (явление «лингвистической моды» на языковые инновации Запада, поликультурность, расширение грании информационного пространства и др.). Проведенный мониторинг современных украинских медиа позволил проанализировать причины тиражирования и закрепления в массовом сознании инновационной лексики/фразеологии.

Ключевые слова: языковые инновации, медиаресурс, медиалингвистика, электронная картотека, психолингвистика, стилистика украинского языка. 